\title{
Reprodução medicamente assistida: questões bioéticas
}

Sandrina Maria Araújo Lopes Alves ${ }^{1}$, Clara Costa Oliveira ${ }^{2}$

\section{Resumo}

Este artigo debruça-se sobre os avanços tecnológicos na reprodução medicamente assistida, investigando que questões bioéticas se colocam quanto a essa questão. Aprofunda os vários posicionamentos sobre situações éticas e jurídicas que este campo de investigação científica levanta, naquilo que parece consensual: o direito à paternalidade. Focaliza a legislação dos países da Comunidade Europeia, na qual se inclui a portuguesa. As conclusões mais significativas são: há, geralmente, legislação comum nos vários países quanto à RMA, existindo, contudo, diferenças em face de algumas questões. A situação mais consensual refere-se à reprodução medicamente assistida até os 14 dias de fecundação. A argumentação bioética quanto às questões levantadas pela RMA alicerça-se, sobretudo, no princípio de autonomia (dos pais), em detrimento de outros princípios, como o da não maleficência e o da dignidade humana.

Palavras-chave: Fertilização in vitro. Bioética. Legislação. União Europeia.

\section{Resumen}

\section{La procreación asistida médicamente: cuestiones bioéticas}

Este artículo se centra en los avances tecnológicos en la procreación médicamente asistida, investigando los dilemas bioéticos que surgen en esta materia. Profundizamos en las diversas posiciones sobre situaciones éticas y legales que este campo de la investigación científica plantea lo que parece consensuado desde el principio: el derecho a la paternidad. Nos centramos en la legislación de los países que constituyen la Comunidad Europea. Por lo general hay una legislación común en los diferentes países sobre la procreación médicamente asistida; hay, sin embargo, diferencias, lo que hizo explícita en el texto. La situación de más consenso se refiere al procreación médicamente asistida hasta 14 días de la fecundación. Los argumentos bioéticos se fundamentan principalmente en el principio de autonomía (de los padres), a expensas de otros principios, como el de la no maleficencia y de la dignidad humana.

Palabras-clave: Fertilización in vitro; Bioética. Ley. Unión Europea.

\section{Abstract \\ Medically assisted procreation: bioethical issues}

This paper focuses on the technological advances concerning medically assisted procreation, investigating bioethical dilemmas that arise in this respect. We deepened the various positions on legal and ethical issues that this field of scientific research raises, which appears consensual from the start (the right to parenthood). We focused on European Community legislation (countries constituting the European Community), which includes Portugal. The most significant conclusions are: there is usually common legislation in the various countries on medically assisted procreation; there are, however, differences, which we made explicit in the text. The most consensus situation refers to medically assisted procreation up to 14 days of fertilization. The bioethical arguments on the issues raised by medically assisted procreation are mainly founded on the principle of autonomy (parents), at the expense of other principles, such as non-maleficent and human dignity. Key words:. Fertilization in vitro; Bioethics. Legislation. European Union.

1. Mestre sandrina.alves@gmail.com Hospital de Viana do Castelo/Ulsam, Viana do Castelo, Portugal. 2. Doutora claracol@ie.uminho. pt - Centro de Estudos Humanísticos e Instituto de Educação da Universidade do Minho, Braga, Portugal.

\section{Correspondência}

Maria Clara Faria da Costa Oliveira - Instituto de Educação, Campus de Gualtar, Universidade do Minho, 4710. Braga, Portugal.

Declaram não haver conflito de interesse. 
As tecnologias médicas de diagnóstico e tratamento permitem, atualmente, respostas para os casais que vivenciam o problema da infertilidade; no entanto, colocam também sérias questões aos níveis individual, social, político, econômico, legal e ético. Com base nas preocupações bioéticas decorrentes da aplicação das técnicas de reprodução medicamente assistida, partimos para esta análise reflexiva exprimindo nosso posicionamento pessoal sobre a temática, assumindo as nossas crenças éticas, conscientes de outros posicionamentos possíveis.

A infertilidade pode trazer sérios empecilhos para número considerável de casais que com ela se confrontam quer pela inviabilidade do projeto da parentalidade, quer por acarretar alguma estigmatização social. Segundo Teloken e Badalotti ${ }^{1}$, um em cada seis casais apresenta problemas de fertilidade e para cerca de $20 \%$ deles a única alternativa é o recurso a técnicas de reprodução medicamente assistida, entendidas como um conjunto de procedimentos laboratoriais que facilitam uma ou várias fases do processo reprodutivo. As tecnologias de reprodução medicamente assistida (RMA) enquadram-se no tratamento de problemas relacionados com a fertilidade, sendo bem claro que o recurso às mesmas deve ser entendido como um método subsidiário, e não alternativo, de reprodução ${ }^{2}$.

Os fatores de infertilidade podem ser absolutos ou relativos, enquadrando-se nas definições de esterilidade ou de hipofertilidade. A esterilidade é entendida como situação irreversível e, portanto, apenas passível de resolução mediante o recurso a técnicas de reprodução medicamente assistida. A hipofertilidade é, muitas vezes, passível de resolução pelo recurso a terapêuticas tradicionais ${ }^{3}$. Sabe-se, atualmente, que grande parte das causas de infertilidade decorre de fatores sociais, nomeadamente a alteração de papéis da mulher e do homem na vida familiar e social, que os colocam perante o desafio da maternidade em idade avançada, com a qual coincidem as questões da hipofertilidade.

Além disso, pode-se também salientar a importância do controle de certos determinantes de saúde ${ }^{4}$ relacionados com a poluição, estresse, tabaco, comportamentos sexuais e a proliferação de infecções sexualmente transmissíveis, entre outros, que constituem causas evitáveis de infertilidade ${ }^{5}$ que justificam o desenvolvimento sustentado de programas de prevenção, educação e aconselhamento no âmbito da sexualidade em particular e da saúde em geral ${ }^{6}$.

As opções médicas incluem as técnicas de reprodução medicamente assistida que, apesar de ao longo do tempo terem permitido a muitos casais a concretização do desejo de maternidade/paternidade, mundialmente levantam imensas questões éticas relacionadas com a dignidade da pessoa, com o seu impacto sob a unidade e estabilidade familiar, com os limites a impor à ciência e com as suas implicações para o futuro da espécie.

\section{Discussão teórica}

Técnicas de reprodução medicamente assistidas

A verdadeira revolução na área da reprodução humana ocorreu a partir de 1978 , com o nascimento do primeiro ser humano produzido fora do organismo materno, ainda que gerado no útero de sua mãe. Graças às técnicas de reprodução assistida, desde então se tem conseguido fazer nascer milhares de crianças que em condições naturais jamais teriam sido originadas.

Por intermédio dessa técnica inúmeras situações de infertilidade conjugal foram resolvidas; no entanto, geraram-se seres humanos cuja origem biológica é diferente daquela que durante milênios marcou a história do humano, estabelecendo-se, assim, uma dissociação entre o afetivo e o biológico, uma rotura entre o ato sexual e a reprodução ${ }^{7}$.

Esse processo levanta simultânea e talvez paradoxalmente imensas e legítimas preocupações decorrentes da simples manipulação em laboratório não só de gametas, mas sobretudo de embriões humanos em pleno decurso do seu desenvolvimento, que têm conduzido cientistas, biólogos, médicos, juristas, teólogos, sociólogos e até políticos a variados debates e reflexão em torno da questão do início da vida humana e da manipulação subjacente a tais técnicas ${ }^{8}$. O desafio, contudo, é conciliar o desenvolvimento da ciência com o respeito à dignidade da pessoa humana ${ }^{9}$.

A ética médica tradicional, que assentava-se, sobretudo, em preocupações relacionadas com a relação médico-paciente, vê-se desafiada e incapaz de dar resposta a questões emergentes em circunstâncias que colocam desafios fulcrais com inegável impacto na sociedade em geral, nas quais os direitos do paciente começam realmente a ser valorizados em detrimento da tônica colocada na compaixão do médico. Passam a valorizar-se questões relacionadas com o consentimento informado: o direito à verdade, à informação e à autonomia ${ }^{10}$.

Em Portugal, o primeiro parecer do Conselho Nacional de Ética para as Ciências da Vida (CNECV) foi publicado em 1993 e paralelamente surgiu uma 
legislação diversa acerca desse assunto extremamente polêmico e cuja controvérsia baseia-se, sobremodo, nos grandes temas da reprodução artificial com doadores e a investigação em embriões humanos $3,2,11$.

As técnicas de reprodução medicamente assistida visam ultrapassar dificuldades em qualquer das fases do processo de reprodução natural ${ }^{12}$. Assim, em termos gerais, pode-se considerar o processo de reprodução natural sumariamente dividido em três fases: a primeira permite a transferência de espermatozoides para o aparelho reprodutor feminino pelo ato sexual; a segunda ocorre com a fusão do gameta feminino e masculino (ou ovócito e espermatozoide) na porção ampolar das trompas uterinas, originando um ovo ou zigoto que inicia o seu processo acelerado e continuado de desenvolvimento celular; a terceira, denominada implantação embrionária (ou nidação), ocorre mediante a implantação desse embrião na mucosa uterina e posterior desenvolvimento da gravidez ${ }^{13}$.

Assim, considerando a causa de infertilidade, as técnicas de reprodução assistida destinam-se a ultrapassar uma ou várias das fases anteriormente descritas.

A relação programada é o processo de planejamento da relação sexual após indução da ovulação por meio de medicamentos. Efetivamente, a estimulação artificial não invade diretamente nenhuma das descritas fases do processo reprodutor, apenas se limita a facilitar a segunda fase pela estimulação da ovulação ${ }^{14}$

Por sua vez, a inseminação artificial intrauterina é considerada um processo de inseminação artificial em sentido próprio, à medida que o sêmen é introduzido no organismo feminino de modo instrumental, facilitando a fecundação. Ou seja: o artificial sobrepõe-se à primeira fase do processo reprodutor natural, em que o ato sexual é condição sine qua non para a deposição dos gametas masculinos no aparelho reprodutor feminino.

A inseminação artificial (IA) pode ser extramatrimonial, quando realizada em mulher solteira ou viúva, ou intramatrimonial. No caso da IA intramatrimonial, pode-se considerar a homóloga, também chamada intraconjugal quando se realiza com o sêmen do companheiro, ou heteróloga, também chamada extraconjugal quando se realiza com recurso a sêmen de doador.

Apesar disso, existem casos em que para além da inseminação artificial de espermatozoides é também necessária a transferência de ovócitos direta- mente para a trompa de Falópio. Esta técnica, hoje considerada ultrapassada, designada como Gift ( $g a-$ metes intrafallopian transfer), permite a inseminação artificial dos dois gametas em separado, possibilitando o seu encontro e eventual fusão in vivo na porção ampolar da trompa de Falópio; é, portanto, invadida artificialmente a primeira fase do processo reprodutor, decorrendo, posteriormente, a gravidez de forma natural ${ }^{15}$.

Quando a causa da infertilidade atinge a segunda fase do processo reprodutor, ou seja, é impossível o encontro e fusão dos gametas ao nível das trompas uterinas, torna-se necessário promover seu encontro extracorporalmente ${ }^{15}$. A fusão gamética extracorpórea abrange a fertilização in vitro (FIV) clássica e a FIV por meio de injeção intracitoplasmática de espermatozoide (Icsi).

Assim, a FIV é um processo mais complexo, que permite a fusão gamética num recipiente de laboratório, daí a vulgar designação de "bebê proveta". Na FIV clássica os espermatozoides e óvulos recolhidos em separado são conjuntamente incubados em meio e temperatura adequados para que ocorra a fecundação, originando-se um ovo ou zigoto que é posteriormente transferido para o aparelho reprodutor feminino de acordo com o seu estádio de desenvolvimento celular ${ }^{15}$.

A Icsi é uma técnica de FIV que se diferencia da clássica pelo fato de se colocar um único espermatozoide diretamente no citoplasma do ovócito, ultrapassando todas as barreiras à fecundação, o que a torna uma técnica de micromanipulação mais invasiva ${ }^{9}$. Trata-se da técnica mais utilizada atualmente e está sobretudo indicada para casais com fator masculino grave ${ }^{16}$.

Assim, pode-se verificar que a FIV e a transferência de embriões ('transferência embrionária - TE', ou Fivete) ou de zigotos, também uma 'transferência embrionária - TE' (Zift - zygote intra fallopian transfer), sobrepõem-se à primeira e segunda fase do processo reprodutor, restando apenas a terceira a dever-se a fenômenos naturais ${ }^{15}$.

Apesar de existir pretensão científica de invadir artificialmente a terceira fase do processo reprodutor natural, colocando-se a possibilidade de conseguir todo o desenvolvimento embrionário in vitro com a construção de um útero artificial sem qualquer relação com o organismo da mulher, este fenômeno denominado ectogênese ainda não foi alcançado ${ }^{15}$.

Com base em Lima ${ }^{15}$ salientamos alguns procedimentos com diferentes graus de complexidade 
e controvérsia, ainda em investigação e/ou aplicados em poucos países que permitem ultrapassar a infertilidade de causas diversas:

- clonagem reprodutiva (obter um ser vivo a partir de núcleos de células somáticas adultas, geneticamente reprogramadas e revertidas ao estado embrionário) - até 2011 somente dois países permitiam pesquisas com clonagem de seres humanos;

- recurso a espermatozoides (bancos de esperma) ou ovócitos provenientes de terceiros para reprodução medicamente assistida (com recurso ao congelamento);

- inseminação post-mortem;

- fecundação assistida de ovócitos por microinjeção de células precursoras de espermatozoides após colheita testicular (em fase de pesquisa);

- desenvolvimento de espermatozoides humanos em laboratório ou em tecido testicular animal (em fase de pesquisa);

- desenvolvimento de ovócitos in vitro a partir de fragmentos de ovário biopsiados ou colhidos de fetos abortados, contendo células germinativas primordiais femininas (em fase de pesquisa).

Além desses casos, destaca-se, em decorrência dos diferentes fins aos quais podem ser destinados, o congelamento de embriões excedentes, em diferentes fases do seu desenvolvimento. A posterior utilização deste excedente após descongelamento pode ser feita: 1) pelo casal a que pertencem biologicamente, na tentativa de gravidez subsequente; 2 ) por outro casal estéril, por doação, para fins reprodutivos; 3) para a obtenção de células estaminais; 4) para a experimentação científica; 5) para descongelação e rejeição; 6) para diagnóstico genético préimplantacional (determinar características genéticas normais ou anormais de um embrião a partir de biopsia celular); 7) para terapia gênica embrionária (corrigir determinadas características "anormais" na fase embrionária), ainda em fase de pesquisa ${ }^{17}$.

Considerando-se a realidade biológica e a descrição sumária das diferentes fases do processo de fecundação e desenvolvimento embrionário, a fecundação consiste na fusão dos gametas feminino e masculino, ou seja, duas células haploides (com um conjunto de cromossomas singulares), o espermatozoide e ovócito, e ocorre fisiologicamente na porção ampolar da trompa de Falópio ${ }^{12}$. Durante sua movimentação ao longo da trompa sofre processos sucessivos de divisão celular e cerca de 30 horas após a fecundação resultam duas células; cerca de
40 a 50 horas depois dá-se nova divisão celular, com formação de 4 células; e após as 60 horas alcança-se o estádio de oito células ${ }^{18}$.

O embrião alcança a entrada do útero no estádio de mórula, ou seja, com 12 a 16 células no $4^{\circ}-5^{\circ}$ dia após a fecundação, no estádio de totipotencialidade, isto é, cada uma destas células pode originar por si só um conjunto de tecidos diferentes e portanto sem individualidade reconhecida. Por volta do $6^{\circ}$ ou $7^{\circ}$ dia o embrião adquire o estado de blastocisto, que progressivamente se implanta no útero entre $\circ 7^{\circ}$ e o $14^{\circ}$ dia mediante um conjunto complexo de fenômenos morfológicos e moleculares do qual participam o embrião e o endométrio, numa interdependência profunda, cuja concretização com êxito depende de perfeita sincronização ${ }^{18}$.

Associado a um continuado desenvolvimento embrionário, para que haja a implantação é necessário que o endométrio possua características ótimas de receptividade, o que ocorre apenas num curto período de dias, designado "janela de implantação", habitualmente entre o $19^{\circ}$ e o $22^{\circ}$ dia de um ciclo ideal de 28 dias ${ }^{12}$. Assim, nesta fase inicia-se um acentuado processo de desenvolvimento embrionário, sendo o primeiro sinal de organização primária o aparecimento da "linha primitiva" que se considera rudimento do sistema nervoso que assinala o começo de uma sensibilidade individual.

Esta linha corresponde ao limite da fase que, segundo Neves ${ }^{19}$, se poderia designar de préembrião. Na mesma obra, se explica que a partir do momento em que se completa a implantação do "pré-embrião" na parede uterina (nidação) e se desenvolve um conjunto de estruturas de ligação entre este e a parede uterina, passa a designar-se embrião. A distinção biológica entre embrião e préembrião (termo não assumido de forma consensual no mundo científico) reside também na diferença de potencial que lhes é reconhecida, sendo que a totipotência, a capacidade do pré-embrião se separar e constituir outro com a mesma informação genética, pertence a um grupo de células, e não a um indivíduo, para autores como o mencionado ${ }^{18}$.

A embriogênese completa-se por volta da $8^{a}$ semana, correspondendo ao desenvolvimento de todas as mais importantes estruturas e órgãos internos e externos. Entre a $8^{\mathrm{a}}$ e $12^{\mathrm{a}}$ semanas de gestação a integração do sistema nervoso central atinge um nível de desenvolvimento apreciável; a partir desta idade gestacional passamos a denominar o novo ser de feto - que completa o seu desenvolvimento até as 40 semanas, momento em que, habitualmente, se planeja a data provável do parto e nascimento ${ }^{18}$. 
Na reprodução natural a dinâmica e cinética global do processo é perfeitamente indissociável. Na reprodução assistida, porém, é perfeitamente possível dissociar no tempo e espaço cada uma das suas fases, mediante o congelamento de gâmetas ou embriões ${ }^{15}$. Assim, se tivermos em consideração o caso da inseminação artificial homóloga, o congelamento de espermatozoides que pode ser utilizado em homens em risco de perder a fertilidade, ou vêla reduzida, representa a dissociação no tempo por período variável. Essa dissociação no tempo pode ir ao ponto de uma viúva ser inseminada com espermatozoides do companheiro falecido.

$O$ recurso a embriões congelados, resultantes de um processo de fertilização in vitro anterior com embriões excedentários (o número de embriões a ser implantados por ciclo depende da lei de cada país. Existem países que permitem apenas um; outros, até quatro. No Brasil, esse número depende da idade da paciente; na União Europeia, o mais usual são três por ciclo) representa não só a dissociação no tempo como no espaço: a recolha de esperma, a fertilização e transferência de embriões podem realizar-se em épocas consideravelmente afastadas, ocorrendo num ou vários locais extracorporais (espaços de laboratório), onde permaneçam durante períodos de tempo indeterminados.

A dissociação temporal e espacial, verificada nas técnicas de reprodução homóloga, sofre ampliação considerável quando se trata da doação de gametas ou do recurso a doação temporária de útero, nos casos de "gestantes de substituição" ${ }^{15}$. Portanto, nos casos de infertilidade masculina ou feminina, com recurso a banco de esperma ou a ovócitos doados, para aplicação de qualquer uma das técnicas de reprodução medicamente assistida, verificar-seia a dissociação das funções biológica e social do pai ou mãe, ou seja, a paternidade/maternidade e a proveniência do material biológico encontram-se dissociadas em pessoas diferentes, verificando-se também uma despersonalização do material reprodutor, garantido pelo anonimato da doação ${ }^{15}$.

Nos casos em que a causa de esterilidade se relaciona com a ausência de útero, ultrapassada pelo recurso a uma mulher estranha ao casal que aceite ser receptora de um ou mais embriões, produzidos in vitro com gametas do casal, e assume o compromisso de aceitar a gravidez e o parto sem, no entanto, considerar o nascituro seu, verifica-se uma acentuação das dissociações anteriormente referidas, já que coincidem com a dissociação entre parto e maternidade e uma eventual despersonalização do processo da gravidez. Este fenômeno de dissociação espaço-temporal das diferentes fases do processo e da função biológica de pai e mãe coloca sérias questões, sobretudo no que se relaciona com as raízes familiares, historicidade e identidade da vida humana dos novos indivíduos ${ }^{15}$.

Vejamos agora as principais questões bioéticas que a reprodução assistida acarreta.

\section{Questões bioéticas}

O desenvolvimento das técnicas de reprodução medicamente assistida, mais especificamente a fecundação in vitro e a consequente produção, manipulação, congelamento e experimentação de embriões, colocam a tônica no estatuto ético, jurídico e ontológico da vida humana desde o seu início e desenvolvimento. Trata-se, portanto, de questão que perpassa necessariamente diversas áreas da ciência, mas que se centra, sobretudo, na biologia (relacionada com a gênese e desenvolvimento do ser humano) e na filosofia (pelo estatuto ético-ontológico dessa vida).

Segundo Neves, a fusão dos gametas feminino e masculino e, portanto, a fecundação, determinariam uma forma de vida diferente da dos gâmetas de onde proveio e cuja identidade genética a define como sendo da espécie humana ${ }^{20}$. Assim, segundo a autora, confirmar-se-ia a partir desse momento a presença de vida humana. Da mesma forma que a passagem desta vida humana para uma vida individualizada poderia ser considerada parte de um processo contínuo, sendo o embrião - ontologicamente - o mesmo ser (adulto) que progressivamente se constitui ao longo do processo de individuação.

É possível, contudo, na biologia, atribuir diferentes estatutos aos vários estádios de desenvolvimento da vida humana, invocando-se usualmente três critérios. Em primeiro lugar, defende-se a ideia de que a nova vida seria um ser humano quando a identidade genética em presença contenha todos os dados necessários para que se torne um ser humano adulto. Considera-se que a identidade genética é constituída a partir do momento em que há a fusão dos gametas feminino e masculino, determinandose assim sua potencialidade para vir a tornar-se um ser humano adulto, muito embora apenas a minoria alcance efetivamente esse estado, devido a complicações em quaisquer das fases de desenvolvimento e implantação.

Estudos recentes indicam que as características biológicas do ser humano adulto não estão determinadas quando da concepção, ou seja, o de- 
senvolvimento embrionário é concomitantemente influenciado pelo ambiente materno. Associada a esta argumentação surge a questão da individualidade, que se sustenta no fato de considerar que o ser humano surge quando da fase de individuação, sendo que a identidade genética e a individuação não coincidem. Só é possível determinar se a identidade genética do zigoto corresponderá a um desenvolvimento singular quando tiver início o processo de embriogênese durante a implantação, portanto, após o aparecimento da linha primitiva ${ }^{20}$.

Por último, é mencionado o critério da viabilidade que sustenta a definição de ser humano na sua capacidade para sobreviver fora do útero materno, ou seja, no ambiente extrauterino. A permanente evolução tecnocientífica tem permitido progressivamente antecipar cada vez mais essa possibilidade, daí que a definição de ser humano ficaria extremamente dependente da possibilidade de sobrevivência do recém-nascido. Este é, dos três critérios mencionados, aquele que reúne o menor consenso ${ }^{20}$.

De fato, a maior controvérsia surge associada às primeiras semanas da vida humana, à sua natureza ontológica e estatuto ético-jurídico, sendo controverso e crucial o momento a considerar para definir o estatuto do embrião, à medida que baliza a tomada de posição relativamente a opções ou decisões. Assim, são duas as principais posições assumidas: uma atribui o estatuto de pessoa a toda vida humana desde o momento da fecundação; outra estabelece como marco para a atribuição do estatuto de pessoa o aparecimento da linha primitiva que ocorre por volta do $14^{\circ}$ dia, quando termina a implantação. Embora assentem no mesmo princípio, para efetuar essa caracterização existem, contudo, diferentes perspectivas.

Os defensores de que a personalidade da vida embrionária se define por volta do $14^{\circ}$ dia convergem na tônica do processo de individuação como fator determinante da personalidade. Assim, perante o zigoto ou designado "pré-embrião", consideram estar em presença de formas de vida humana, mas não propriamente de um ser humano. $\mathrm{O}$ aglomerado de células que constituem o zigoto não permite atribuir-lhe individualidade própria; apenas o embrião é, nesta perspectiva, já uma individualidade que normalmente se desenvolverá como ser humano independente e, portanto, uma entidade ontológica que deve ser respeitada e protegida como pessoa ${ }^{21}$.

$\mathrm{Na}$ União Europeia (organização que engloba 28 países europeus, com dimensão política, econômica e legal articuladas entre todos) é consensualmente aceito que o embrião não deve ser sujeito a nenhuma forma de experimentação depois do aparecimento da linha primitiva; no entanto, não há uma orientação europeia global em face dos procedimentos a adotar em relação à 'vida humana' durante as duas primeiras semanas. Ao considerar-se o embrião como pessoa dever-se-ia respeitar e preservar a vida humana desde o $14^{\circ}$ dia após a fecundação, após o aparecimento da linha germinativa ${ }^{21}$.

Em relação aos defensores de que, sob o ponto de vista ético-jurídico, o embrião desde a sua fecundação merece o mesmo respeito e proteção que a pessoa adulta, existem sobretudo duas vias de fundamentação. A primeira privilegia a pertença ontológica à espécie humana, ou seja, a carga genética seria suficiente para Ihe atribuir existência própria e autonomia intrínseca, que o tornariam pessoa que merece o devido respeito e proteção jurídica. $A$ segunda via privilegia o potencial da vida humana desde o seu começo, ou seja, a entidade ontológica que surge desde a fusão dos gametas feminino e masculino ao possuir potencial para se transformar numa pessoa seria suficiente para ser tratada como tal. O zigoto é, portanto, encarado como uma pessoa potencial.

Mesmo no que se refere às diferentes posições assumidas em face do estatuto do embrião, não se reúne também consenso, na União Europeia, em relação às definições de ser humano e pessoa, embora sejam usados como sinônimos. No entanto, para alguns, o termo pessoa remete a nível superior de desenvolvimento humano, posterior ao nascimento, em que à diferenciação ou individuação ontológica se acrescenta a especificidade moral. Na distinção entre ser humano e pessoa importa ainda salientar que se atribui, por outros, valor moral não só à pessoa, mas também ao ser humano, em virtude do incondicional respeito pela dignidade humana, que é um dom com que todos os membros da nossa espécie nascem ${ }^{22}$.

Isto torna-se particularmente relevante para o caso de pacientes em estado vegetativo, anencéfalos ou outros, como é o caso do embrião (a ser considerado pessoa humana) cujas particularidades Ihe impedem o exercício de um conjunto de deveres mas cujos direitos teriam de ser necessariamente respeitados e defendidos, pelo que constituiria a vida humana como potencial para a constituição da pessoa que seria sempre digna de respeito ético e de proteção legal, independentemente da fase em que esta se considerasse ${ }^{8}$.

Segundo Santos, Renaud e Cabral ${ }^{7}$, no que se refere à designação de pessoa, importa considerar que a biologia é responsável pelo reconhecimento do aparecimento de um novo ente humano, caben- 
do à ética afirmar que esse ente humano é pessoa, à proporção que a identidade pessoal é complexa, desenvolve-se num contínuo e escapa ao olhar microscópico da biologia. Assim, se a pessoa é movimento contínuo de um devir biológico, e de um devir que é também psicológico, social, cultural, ético e espiritual, então este devir tem filosoficamente que ser encarado sem cortes, isto é, no seu movimento de realização e de progressiva totalização ${ }^{7}$.

\section{Consensos e divergências}

A reprodução homóloga, desde que realizada em favor de casais heterossexuais, cuja relação se considere estável e não encontrem outra via para resolução da infertilidade/esterilidade devidamente confirmada, reúne amplo consenso na Europa comunitária ${ }^{15}$. A lei portuguesa é também clara neste sentido, entendendo que a RMA só deve ser considerada mediante o diagnóstico de infertilidade ou perante doença grave de transmissão genética, em casais de sexo diferente, com relação estável há pelo menos dois anos, idades superiores a 18 anos e sem patologia psíquica associada ${ }^{2}$.

Pode-se então salientar o consenso na condenação de um conjunto alargado de procedimentos na área da reprodução artificial na Europa comunitária ${ }^{15}$, frente aos quais se pode estabelecer paralelismo com a lei portuguesa (Lei 32/2006 e Lei 12/2009). A inseminação post-mortem ou a reprodução de uma mulher ou homem isolado (por recurso a banco de esperma ou mãe de substituição, respectivamente) são condenados. A lei espanhola contraria esta posição e permite a inseminação post-mortem nos seis meses seguintes ao falecimento do doador e com escritura pública para o efeito, bem como o recurso por parte de uma mulher isolada a banco de esperma. A lei portuguesa proíbe a utilização do esperma, mas permite a transferência de embrião assumido como projeto parental antes da morte do pai ${ }^{2}$.

$O$ recurso a gestantes de substituição, e a sua associação a fins de comercialização, é condenado na União Europeia. No entanto, existe certa disparidade em considerar a possibilidade de recurso a gestante de substituição por irmãs ou parentes próximos perante a morte da mulher alvo da transferência de embrião, sem associação a fins lucrativos. Embora em discussão, a lei portuguesa, por exemplo, não permite a maternidade de substituição, considerando que a mulher que se submeter a tal procedimento é vista, para efeitos legais, mãe da respectiva criança.

O recurso a técnicas de reprodução artificial para obter características especiais da criança é condenado na União Europeia, mas não há consenso no que respeita à possibilidade de impedir a transmissão de doenças genéticas ligadas ao sexo, tal como acontece na lei portuguesa ${ }^{2}$. A recolha de embriões por lavagem uterina antes da nidação para implantação noutra é também condenada, sobretudo pelos riscos para o embrião. A clonagem, a transferência de embriões humanos para o útero de outra espécie ou vice-versa, bem como a fusão de gametas ou embriões humanos com gametas ou embriões de outras espécies são procedimentos condenados na União Europeia.

A criação de embriões in vitro para experimentação, à exceção da lei britânica, é também consensualmente condenada na União Europeia, bem como a experimentação em embriões produzidos in vitro e depois implantados no útero, atribuindoIhes proteção idêntica à dos embriões produzidos in vivo. A experimentação no embrião após os 14 dias é consensualmente condenada ${ }^{23-25}$.

Segundo o Conselho Nacional de Ética para as Ciências da Vida (CNECV), organismo português, a fundamentação ética, no que se relaciona com as tecnologias de reprodução humana, deve apoiar-se no conceito de natureza humana, não numa perspectiva meramente biológica, mas integrando as diferentes dimensões da vida que confluem numa constante procura de realização pessoal. Assim, cada pessoa deveria ser entendida como ser único e irrepetível e tratada como um fim em si mesma, e não como um meio, o que significa que a opção pelas tecnologias de reprodução humana e suas implicações não podem ser analisadas unicamente em função dos pais ${ }^{7}$. Os dois princípios éticos fundamentais na aplicação das técnicas de reprodução medicamente assistida podem enquadrar-se, neste posicionamento, na não instrumentalização da pessoa humana e na dignidade humana ${ }^{18}$.

A este propósito importa considerar o testemunho de Jacques Testard, cientista responsável pelo nascimento da primeira bebê proveta Louise Brown, em 1978: (...) decidi fazer uma paragem neste caminho. Não para travar a investigação que nos ajude a melhorar o que estamos a fazer, mas para travar aquela investigação que tem por objetivo uma mudança radical da pessoa humana, ali onde a medicina procriativa está em conexão com a preditiva ${ }^{16}$.

\section{Considerações finais}

Quanto a nós, as manipulações que afetam o corpo sem trazer benefício para a identidade do ser 
humano manipulado opõem-se à responsabilidade que, diante de si próprio, o ser humano tem por si e pelos outros ${ }^{26}$. A responsabilidade humana tem de ser considerada como resposta a uma exigência de respeito ativo e não como poder arbitrário para remodelar o corpo segundo desejos da ciência e técnica. Não se trata de paralisar a ciência e técnica, mas antes de ponderar a manipulação biológica que tem a espécie como objeto ${ }^{7}$. 0 respeito pela liberdade ética implica que a opção pela RMA seja uma decisão livre que evite projetar sobre o nascituro uma carga instrumental que o transforme num objeto a obter a qualquer custo.

A autonomia significa, em termos gerais, a ausência de imposições ou coações externas que impeçam ou diminuam a capacidade de decisão. No entanto, a aplicação desse princípio deve ser balizada pelo respeito por outros princípios axiológicos, nomeadamente o da beneficência e o da justiça, ou seja, não lhe pode ser atribuído primado absoluto e a sua aplicação não é incondicional ${ }^{27}$.

No princípio da não maleficência, a tônica coloca-se em perceber que não há razões que justifiquem, em determinadas circunstâncias, causar dano a alguém. É à luz deste princípio que se examina a questão da diferença entre matar e deixar morrer ou entre o voluntário direto e o indireto. Este é, também, o princípio que desencadeia a discussão para o princípio de duplo efeito, ou seja, em circunstâncias bem definidas seria legítimo realizar ações que resultariam num efeito bom (pretendido) associado a outro efeito mau, que no contexto se pode considerar tolerado, enquadrando-se perfeitamente na avaliação e ponderação ética de cada caso de aplicação de técnicas de RMA.

O princípio da justiça surge na bioética associado a exigências de cariz distributivo, ou seja, baseado na preocupação de distribuição justa de recursos e meios por vezes escassos ou limitados, o que origina graves problemas ao nível das macro e das microdecisões ${ }^{28}$ e que são bem patentes na seleção dos casais para aplicação de técnicas de RMA. Atualmente, este é um problema em destaque, dado o fato de muitos casais serem obrigados a recorrer ao sistema privado de saúde para ter resolvidos os seus problemas de infertilidade/esterilidade.

$\mathrm{O}$ direito à integridade pessoal e à proteção da saúde, se considerados, criariam limites à experimentação, pelo direito a não nascer, pelo direito a um patrimônio genético não manipulado, pelo direito à identidade pessoal e pela proibição do anonimato do doador de gametas, pelo direito a uma família biparental. A experimentação apenas deveria ser considerada, então, no caso de contribuir para o bem do próprio embrião, isto é, a chamada experimentação terapêutica.

Não tendo o embrião possibilidade de exprimir sua vontade, Loureiro considera que, para o bem do próprio embrião, apenas deve ser admitida a experimentação caso não se vislumbre alternativa eficaz de tratamento. É óbvio que a prática médica torna por vezes obscura a distinção entre esses dois fenômenos. No entanto, deve ser considerado terapêutico o tratamento cujos meios correspondem aos estandartes normais reconhecidos pela prática médica - no caso da experimentação terapêutica entra-se no território da terapia inovativa ${ }^{28}$.

Em consonância com este posicionamento, a Convenção dos Direitos Humanos e Biomedicina condena também a experimentação em embriões que se considerem inevitavelmente condenados a morrer, mesmo que essas experiências contribuam para o desenvolvimento do conhecimento científico, com potencial benefício para os seres humanos existentes ou a existir.

O direito do embrião a não ser implantado caso revele graves malformações é considerado, o que se revela oposto ao princípio do direito à vida. Também o direito a um patrimônio genético não manipulado reitera a importância de preservar os direitos das gerações futuras ${ }^{29}$. Essas posições levantam questões para pensar: por que o embrião com malformação merece ser tratado com menos dignidade? Não estaremos a contribuir para a eugenia da espécie? De fato, paralelamente à reivindicação ao direito a ter filhos, levanta-se também a questão da possibilidade de selecionar as suas características ${ }^{7,9,17}$.

O direito à identidade pessoal e proibição do anonimato do doador é também polêmico, no caso da reprodução heteróloga, centrando-se no direito de conhecer sua identidade biológica. Colide, porém, com o direito à reserva da intimidade da vida privada e familiar, relacionando-se com a construção dos processos de maternidade e paternidade, podendo alterar o desenvolvimento harmônico da unidade familiar e o projeto parental, com reflexos no desenvolvimento futuro da criança ${ }^{7}$.

O direito a uma família biparental justifica que não seja constitucionalmente admissível a inseminação de mulher solteira, que não viva uma relação heterossexual em união de fato estável, ou postmortem. Nenhuma dessas características é, contudo, impeditiva da adoção, quer no que respeita a mulheres/homens solteiros, quer a casais não hete- 
rossexuais, o que tem salientado a necessidade da discussão social dessas questões, não a remetendo apenas para os cientistas, legisladores e políticos.

Ainda segundo Loureiro ${ }^{29}$, poder-se-ia legislar especificamente para embriões in vitro, à medida que sua condição os torna mais vulneráveis ao risco de agressão. Assim, apesar das políticas punitivas no que se refere à produção de embriões excedentários, a criopreservação é uma realidade sem que o seu destino seja necessariamente a implantação nos seus progenitores de origem e o seu fim pode resultar na doação, na experimentação ou mesmo na sua destruição. A destruição do embrião interferiria com o seu direito à vida e integridade física ao impedir o seu normal desenvolvimento, do mesmo modo que se levantaria também a questão da temporalidade da vida humana com possíveis saltos geracionais e impossibilidade de relações parentais para os casos da criopreservação por períodos prolongados.

O direito a não ser clonado é outro direito referido, pois atentar-se-ia sobre a integridade física do embrião, a dignidade humana e a própria identidade pessoal. A possibilidade de implantação do embrião noutras espécies atentaria contra o princípio da dignidade humana, devendo ser totalmente rejeitada. Os referidos direitos não são absolutos, significando que daqui emergem conflitos entre o embrião e a mãe, os investigadores e outros terceiros. Assim, a mãe deveria abster-se de condutas que coloquem em risco o embrião, ou sujeitar-se a intervenções que coloquem a sua vida em risco em benefício da vida deste. Neste caso entram em jogo a autonomia da mulher, o seu direito à integridade física, à saúde ou mesmo à vida.
Consideramos existir, usualmente, uma hipervalorização do princípio da autonomia dos potenciais pais, em detrimento dos princípios de beneficência e não maleficência. Quando, no entanto, se reverte esta situação, surge a proibição do excesso, exigindo-se cuidadosa avaliação do grau de intrusão da intervenção, do seu real ou potencial benefício para o embrião, bem como a possibilidade de se estar perante uma intervenção de experimentação e não propriamente terapêutica.

Quanto à experimentação em embriões vivos, pode ser admitida a experimentação terapêutica no embrião quando se tenciona reconhecer, impedir ou eliminar uma doença, correspondendo ao respeito pelos seus direitos à vida, saúde e integridade física ${ }^{29}$. Diversas hipóteses são porém configuráveis: 1) experimentação terapêutica em prol do bem do próprio embrião; 2) experimentação com embriões excedentários quando tal se mostre adequado e necessário para assegurar a vida e a saúde de terceiros e; 3 ) embriões exclusivamente produzidos com fins de investigação.

De fato, a dignidade humana proíbe a instrumentalização da vida ${ }^{30}$, pelo que o embrião constitui um objeto passível de manipulação sem que para tal dê o seu consentimento (algo que também não poderia ser feito pelos pais) e sem garantia de relação adequada entre o perigo e as vantagens do ato, o que, em conjunto, transformam, no nosso entender, o embrião num ser humano vulnerável ${ }^{31}$. Diante disso deve imperar a proibição da experimentação. Quando falamos em dignidade humana, há que salientar a proteção post-mortem dos embriões, já que a morte não os deve converter em lixo desrespeitosamente manipulável, comercializável etc.

\section{Referências}

1. Teloken C, Badalotti M. Bioética e reprodução assistida. Revista AMRIGS. 2002;46(3-4):100-4.

2. Portugal. Assembleia da República Portuguesa. Lei $n^{\circ} 32$, de 26 de julho de 2006. Procriação medicamente assistida. Diário da República. 2006;(143): Série I ,5.245-50.

3. Portugal. Conselho Nacional de Ética para as Ciências da Vida. Relatório: parecer sobre reprodução medicamente assistida. (3/CNECV/93). In: Documentação CNECV. 1993 (acesso 23 dez. 2012);1:75-103. Disponível: http://www.cnecv.pt/admin/files/data/docs/1273059600_ P003_PMA.pdf

4. Tingen C, Stanford JB, Dunson DB. Methodologic and statistical approaches to studying human fertility and environmental exposure. Environ Health Perspect. 2004;112(1):87-93.

5. Roupa Z, Polikandrioti M, Sotiropoulou P, Faros E, Koulouri A, Wozniak G et al. Causes of infertility in women at reproductive age. HSJ. 2009;3(2):80-7.

6. Portugal. Direção-Geral da Saúde. Programa Nacional de Saúde Reprodutiva. Lisboa: DGS; 2008 p. 16.

7. Santos AA, Renaud M, Cabral RA. Relatório procriação medicamente assistida. Lisboa: Conselho Nacional de Ética para as Ciências da Vida; 2004 (acesso 23 dez. 2012). Disponível: http://www. cnecv.pt/admin/files/data/docs/1273057205_P044_RelatorioPMA.pdf

8. Neves MCP. O começo da vida humana. In: Archer L, Biscaia J, Osswald W. Bioética. Lisboa: Verbo; 1996. p. $175-83$. 
9. Figueiredo HMVS. A procriação medicamente assistida e as gerações futuras. Coimbra: Gráfica de Coimbra; 2005.

10. Archer L. Fundamentos biológicos. In: Archer L, Biscaia J, Osswald W. Op. cit. p. 17-33.

11. Portugal. Assembleia da República Portuguesa. Lei $n^{\circ} 12$, de 26 de março de 2009. Estabelece o regime jurídico da qualidade e segurança relativa à dádiva, colheita, análise, processamento, preservação, armazenamento, distribuição e aplicação de tecidos e células de origem humana. Diário da República. 2009;(60):Série I, p. 1.876-97.

12. Calhaz J. Ovulação, fecundação e implantação. In: Graça L et al. Lisboa: Lidel; 2005. p. 3-15.

13. Santos M. Injeção intracitoplasmática de espermatozoides: questões éticas e legais. Rev Bras Saúde Matern Infant. 2010;10(2 Suppl):289-96.

14. Tognotti E. Esterilidade: fator ovulatório. In: Pinotti JA, Barros AC. Ginecologia moderna. Rio de Janeiro: Revinter; 2004. p. 294-304.

15. Lima A. Bioética e antropologia. Coimbra: Gráfica de Coimbra; 2004.

16. Izzo V, Izzo C. Fertilização assistida. In: Pinotti J, Barros A. Ginecologia moderna. Rio de Janeiro: Revinter; 2004. p. 305-9.

17. Lima A. Op. cit. p. 178.

18. Neves MCP. Op. cit. p. 175-83.

19. Neves MCP. Op. cit. p. 177

20. Neves MCP. Op. cit. p. 175.

21. Portugal. Conselho Nacional de Ética para as Ciências da Vida. Parecer $n^{\circ} 74$, de julho de 2013. Parecer sobre o protocolo adicional à convenção sobre os direitos do homem e a biomedicina, relativo à investigação biomédica (74/CNECV/2013). CNECV; jun. 2013 (acesso 30 dez. 2013). Disponível: http://www.cnecv.pt/admin/files/data/docs/1374748810_P74\%20CNECV\%202013\%20 Prot\%20Adic\%20Invest\%20Biomedica.pdf

22. Organização das Nações Unidas. Declaração Universal dos Direitos Humanos. [Internet]. Adotada e proclamada pela resolução 217 A (III) da Assembleia Geral das Nações Unidas em 10 de dezembro de 1948 (acesso dez. 2013). Disponível: http://portal.mj.gov.br/sedh/ct/legis_intern/ ddh_bib_inter_universal.htm

23. Conselho da Europa. Convenção para proteção dos direitos do homem e da dignidade do ser humano face às aplicações da biologia e da medicina. [Internet]. 1997 (acesso 2 jun. 2010). Disponível: http://www.gddc.pt/direitos-humanos/textos-internacionais-dh/tidhregionais/convbiologiaNOVO. html

24. McGleenan T. As implicações éticas da investigação em embriões humanos: estudo final. Luxemburgo: Parlamento Europeu; 2000.

25. Martin I, Baldomero H, Bocelli-Tyndall C, Emmert MY, Hoerstrup SP, Ireland $\mathrm{H}$ et al. The survey on cellular and engineered tissue therapies in Europe in 2011. [Internet]. Tissue Eng Part A. 2014 (acesso jan. 2014);20(3-4):842-53. Disponível: http://www.ncbi.nlm.nih.gov/pubmed/24090467

26. Jonas H. Ética, medicina e técnica. Lisboa: Veja; 1994.

27. Cabral R. Temas de ética. Braga: Universidade Católica Portuguesa; 2003.

28. Oliveira CC, Meireles ACPR. Bioética e saúde global: cuidados primários como instrumento de justiça social. Rev. bioét. (Impr.). 2012;20(1):28-40.

29. Loureiro J. Tomemos a sério os direitos do embrião e do feto. Cadernos de Bioética. 1997;14:3-63.

30. Fontelles C. Família e vida humana. Acção Médica. 2012;LXXVI(2):11-4.

31. Conselho da União Europeia. Diretiva 2001/20/CE do Parlamento Europeu e do Conselho de 4 de abril de 2001. Relativa à aproximação das disposições legislativas, regulamentares e administrativas dos Estados-Membros respeitantes à aplicação de boas práticas clínicas na condução dos ensaios clínicos de medicamentos para uso humano. Jornal Oficial das Comunidades Europeias. [Internet]. $1^{\circ}$ maio 2001(acesso jan. 2014):121-34. Disponível: http://eur-lex.europa. eu/LexUriServ/LexUriServ.do?uri=OJ:L:2001:121:0034:0044:PT:PDF

\section{Participação das autoras}

Todas as etapas do artigo foram produzidas em conjunto por ambas as autoras.

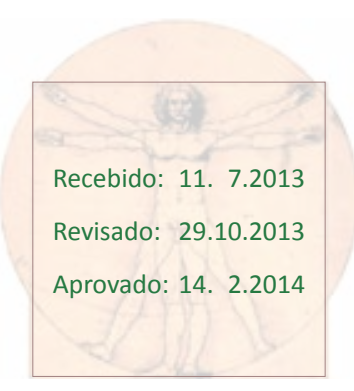

